\title{
Pengaruh Capital Adequacy Ratio, Non Performing Financing Dan Laba Bersihterhadap Financial Sustainability Ratio (Pada Perusahaan Perbankan Syariah Yang Ada Di Indonesia Periode 2014-2018)
}

\author{
Mulia Alim \\ alim17mt@gmail.com \\ Fakultas Ekonomi dan Bisnis Universitas Muhammadiyah Tangerang \\ Daniel Ibnu Sina \\ dibnusina@gmail.com
}

\begin{abstract}
The purpose of this study was to determine the effect of Capital Adequacy Ratio, Non Performing Financing and Net Profit on Financial Sustainability Ratio in Islamic Banking companies in Indonesia. The time period of the study is 5 years, namely the 20152018 period.

The population of this study includes all Islamic Banking companies in Indonesia for the period of 2015-2018. The sampling technique uses purposive sampling technique. Based on predetermined criteria obtained by 10 companies. The type of data used is secondary data obtained from the respective Banking website. The analytical method used is panel data regression analysis.

The results showed that the Capital Adequacy Ratio, Non Performing Financing and Net Profit had a positive effect on the Financial Sustainability Ratio Capital Adequacy Ratio, Non Performing Financing and Net Profit together positively influenced the Financial Sustainability Ratio
\end{abstract}

Keywords : capital adequacy ratio, non performing financing, net profit, financial sustainability ratio

Abstrak
Tujuan dari penelitian ini untuk mengetahui pengaruh Capital Adequacy Ratio, Non Performing Financing dan Net Profit terhadap Financial Sustainability Ratio pada perusahaan Perbankan Syariah yang ada di Indonesia. Periode waktu penelitian yang digunakan adalah 5 tahun yaitu periode 2015-2018.

Populasi penelitian ini meliputi seluruh perusahaan Perbankan Syariah yang ada di Indonesia periode 2015-2018. Teknik pengambilan sampel menggunakan teknik purposive sampling. Berdasarkan kriteria yang telah ditetapkan diperoleh 10 perusahaan. Jenis data yang digunakan adalah data sekunder yang diperoleh dari situs Perbankan masing-masing. Metode analisis yang digunakan adalah analisis regresi data panel.

Hasil penelitian menunjukkan bahwa Capital Adequacy Ratio, Non Performing Financing dan Net Profit berpengaruh positif terhadap Financial Sustainability Ratio Capital Adequacy Ratio, Non Performing Financing dan Net Profit secara bersama-sama berpengaruh positif terhadap Financial Sustainability Ratio.

Kata Kunci : rasio kecukupan modal, pembiayaan bermasalah, laba bersih, rasio keuangan sustainability 


\section{PENDAHULUAN}

Perbankan adalah salah satu motor penggerak ekonomi nasional. Indonesia mulai melakukan deregulasi perbankan pada 1983, saat itu Bank Indonesia (BI) memberikan keleluasaan kepada bank untuk menetapkan suku bunga. Berdasarkan laman ojk.go.id pemerintah berharap dengan kebijakan deregulasi akan tercipta kondisi bank yang efisien dan kuat dalam menopang perekonomian. Masih pada 1983, pemerintah Indonesia berencana menerapkan sistem bagi hasil dalam perkreditan yang merupakan konsep dari perbankan syariah, akhirnya 5 tahun kemudian, pemerintah mengeluarkan paket kebijakan deregulasi perbankan 1988 (Pakto 88) yang membuka kesempatan seluasluasnya untuk bisnis perbankan dalam menunjang pembangunan. Namun lebih banyak bank konvensional yang berdiri. Tapi beberapa usaha perbankan yang bersifat daerah yang berasaskan syariah juga mulai bermunculan. Majelis Ulama Indonesia (MUI) pada 1990 membentuk kelompok kerja untuk mendirikan Bank Islam di Indonesia. Pada tanggal 18 - 20 Agustus 1990, Majelis Ulama Indonesia (MUI) menyelenggarakan lokakarya bunga bank dan perbankan di Cisarua, Bogor, Jawa Barat. Hasil lokakarya tersebut kemudian dibahas lebih mendalam pada Musyawarah Nasional IV MUI di Jakarta 22 - 25 Agustus 1990, yang menghasilkan amanat bagi pembentukan kelompok kerja pendirian bank Islam di Indonesia. Kelompok kerja dimaksud disebut Tim Perbankan MUI dengan diberi tugas untuk melakukan pendekatan dan konsultasi dengan semua pihak yang terkait.

Landasan hukum operasi bank yang menggunakan sistem syariah, saat itu hanya diakomodir dalam salah satu ayat tentang "bank dengan sistem bagi hasil" pada UU No. 7 Tahun 1992; tanpa rincian landasan hukum syariah serta jenis-jenis usaha yang diperbolehkan. Pada tahun 1998, pemerintah dan Dewan Perwakilan Rakyat melakukan penyempurnaan UU No. 7/1992 tersebut menjadi UU No. 10 Tahun 1998, yang secara tegas menjelaskan bahwa terdapat dua sistem dalam perbankan di tanah air (dual banking system), yaitu sistem perbankan konvensional dan sistem perbankan syariah. Peluang ini disambut hangat masyarakat perbankan, yang ditandai dengan berdirinya beberapa Bank Islam lain, yakni Bank IFI, Bank Syariah Mandiri, Bank Niaga, Bank BTN, Bank Mega, Bank BRI, Bank Bukopin, BPD Jabar dan BPD Aceh dll.

Pengesahan beberapa produk perundangan yang memberikan kepastian hukum dan meningkatkan aktivitas pasar keuangan syariah, seperti: (i) UU No.21 tahun 2008 tentang Perbankan Syariah; (ii) UU No.19 tahun 2008 tentang Surat Berharga Syariah Negara (sukuk); dan (iii) UU No.42 tahun 2009 tentang Amandemen Ketiga UU No.8 tahun 1983 tentang PPN Barang dan Jasa.

Dengan telah diberlakukannya Undang-Undang No.21 Tahun 2008 tentang Perbankan Syariah yang terbit tanggal 16 Juli 2008, maka pengembangan industri perbankan syariah nasional semakin memiliki landasan hukum yang memadai dan akan mendorong pertumbuhannya secara lebih cepat lagi.

Dengan proses perkembangannya yang impresif, yang mencapai rata-rata pertumbuhan aset lebih dari $65 \%$ pertahun dalam lima tahun terakhir, maka diharapkan peran industri perbankan syariah dalam mendukung perekonomian nasional akan semakin signifikan. Lahirnya UU Perbankan Syariah mendorong peningkatan jumlah BUS dari sebanyak 5 BUS menjadi 11 BUS dalam kurun waktu kurang dari dua tahun (2009-2010).

Sejak mulai dikembangkannya sistem perbankan syariah di Indonesia, dalam dua dekade pengembangan keuangan syariah nasional, sudah banyak pencapaian kemajuan, baik dari aspek kelembagaan dan infrastruktur penunjang, perangkat regulasi dan sistem pengawasan, maupun awareness dan literasi masyarakat terhadap layanan jasa keuangan syariah.

Karakteristik sistem perbankan syariah yang beroperasi berdasarkan prinsip bagi hasil memberikan alternatif sistem perbankan yang saling menguntungkan bagi 
masyarakat dan bank, serta menonjolkan aspek keadilan dalam bertransaksi, investasi yang beretika, mengedepankan nilai-nilai kebersamaan dan persaudaraan dalam berproduksi, dan menghindari kegiatan spekulatif dalam bertransaksi keuangan. Dengan menyediakan beragam produk serta layanan jasa perbankan yang beragam dengan skema keuangan yang lebih bervariatif, perbankan syariah menjadi alternatif sistem perbankan yang kredibel dan dapat dinimati oleh seluruh golongan masyarakat Indonesia tanpa terkecuali.

Dalam konteks pengelolaan perekonomian makro, meluasnya penggunaan berbagai produk dan instrumen keuangan syariah akan dapat merekatkan hubungan antara sektor keuangan dengan sektor riil serta menciptakan harmonisasi di antara kedua sektor tersebut. Semakin meluasnya penggunaan produk dan instrumen syariah disamping akan mendukung kegiatan keuangan dan bisnis masyarakat juga akan mengurangi transaksitransaksi yang bersifat spekulatif, sehingga mendukung stabilitas sistem keuangan secara keseluruhan, yang pada gilirannya akan memberikan kontribusi yang signifikan terhadap pencapaian kestabilan harga jangka menengah-panjang.

Selama ini cita-cita untuk meraih market share di atas 5\% memang sudah terpenuhi. Itu pun karena ada konversi bank umum konvensional menjadi syariah. Bukan karena organic growth, melainkan karena adanya konversi Bank BPD Aceh menjadi Bank Aceh Syariah dan sebentar lagi Bank NTB. Saat ini market share perbankan syariah sudah mencapai $8,26 \%$.

Penetrasi pasar perbankan syariah memang sudah sedikit membesar, tapi apakah secara kualitas sudah menunjukkan perbaikan? Menurut catatan Biro Riset Infobank (birI), kinerja perbankan syariah tak kunjung membaik sejak 2012. Kejatuhan harga komoditas dan mineral juga menyebabkan perbankan syariah harus bergelut dengan pembiayaan bermasalah.

Lihat saja return on asset (ROA) perbankan syariah yang terus menurun. Pada 2012 ROABank Syariah di Indonesia masih bertengger di 1,77\%, setahun berikutnya menurun dan terus menurun hingga puncaknya terjadi pada 2015 dengan ROA -1,72\%. Pada 2018 ROA Bank Syariah di Indonesia sebesar $-0,10 \%$. Secara kualitas, perbankan syariah belum membaik. Soal pembiayaan bermasalah masih menjadi pekerjaan rumah.

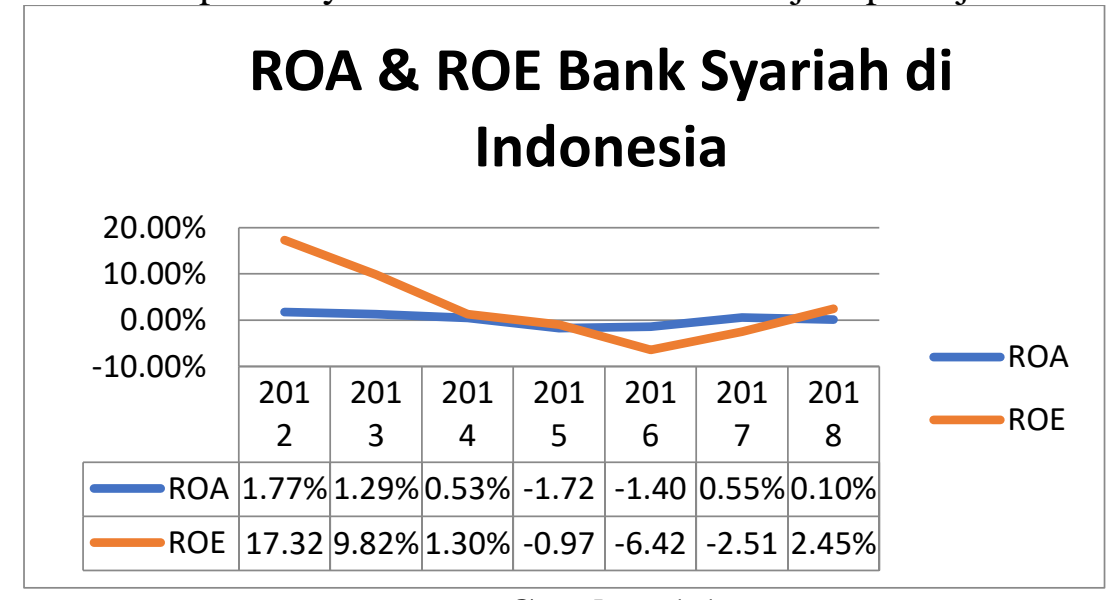

Gambar 1.1

ROA dan ROE Bank Syariah di Indonesia 2012-2018

Sumber : Annual Report Perbankan Syariah di Indonesia (Rata-rata)

Pembiayaan dari perbankan syariah masih menjadi pekerjaan rumah yang harus di kembangkan, inovasi serta memberi produk yang dapat menarik minat para nasabah, dan menyebabkan NPF Perbankan Syariah menurun. Menurunnya NPF pada hal ini juga terjadi pada beberapa perbankan Syariah di Indonesia, yang dikarenakan kurangnya minat masyarakat terhadap produk yang ditawarkan perbankan syariah, di tahun 2016 terlihat NPF Gross Bank Syariah, berada di posisi yang cukup tinggi yaitu 9,64\%, setahun berikutnya menurun, hingga pada 2018 sampai di 3,28\%, begitupun pada NPF Net di 
tahun 2016 berada di posisi 4,14\%, dan ditahun 2017 sempat naik berada di posisi 4.20\%hingga di tahun 2018 terjadi penurunan kembalidi posisi 2,18\%, sangat terlihat sekali terjadi penurunan yang cukup signifikan, sehingga akan berdampak kepada Financial Sustainability RatioPerbankan Syariah yang ada di Indonesia.

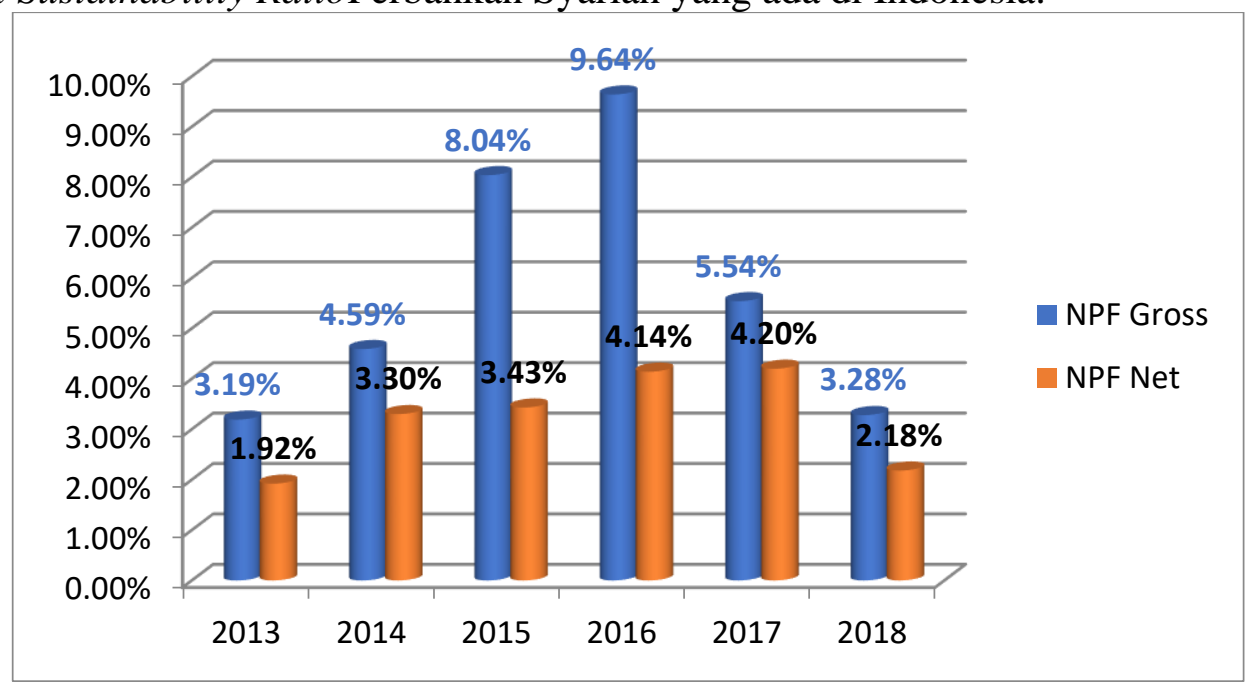

Gambar 1.2

NPF Gross \& NPF Net Bank Syariah di Indonesia 2012-2018

Sumber : Annual Report bank Syariah di Indonesia (Rata-rata)

Potensi berkembangnya perbankan syariah di Indonesia memang relatif besar. Penduduk yang beragama Islam di Indonesia adalah mayoritas-dengan dukungan kebijakan dari Majelis Ulama Indonesia (MUI) yang menyatakan bahwa bunga bank riba. Namun, toh perkembangan perbankan syariah tidak fantastis dari sisi kualitas.

Indonesia hanya mampu berada di urutan kesembilan dari 10 negara Islam lainnya, dari sisi aset industri jasa keuangan syariah. Ada kelemahan yang memicu perbankan syariah Indonesia lambat berkembang. Perbankan syariah saat ini hanya memfokuskan pada fungsi sebagai bank komersial biasa, tidak memaksimalkan fungsi sebagai bank investasi.

Bahkan, bisa disebut orientasi bank syariah berjangka pendek, yaitu menyalurkan pembiayaan konsumtif jangka pendek. Sebenarnya, hal ini tidak keliru karena memang ada sisi kompetensi yang kurang memadai jika bergerak pada pembiayaan investasi. Harusnya ini yang membedakan perbankan syariah dan konvensional.

Bahan baku bankir perbankan syariah bersumber dari bank konvensional. Hal ini tidak menjadi masalah yang serius karena usia perbankan syariah sudah mendekati tiga dekade - seharusnya masalah kompetensi tidak jadi soal. Kenyataannya, pada 2012 kinerja bank syariah merosot dan sampai dengan saat ini sulit untuk bangun.

Produk-produk yang ditawarkan bank syariah pun tidak beragam. Service level masih kalah jauh dibandingkan dengan bank konvensional. Jadi, ketentuan wajib konversi bank syariah pada dua tahun mendatang pun menjadi sangat berat bagi usaha unit syariah (UUS) - karena harus ada investasi sendiri dalam pengembangan usaha ke depannya.

Selain orientasi dan kompetensi bankir syariah dalam mengembangkan syariah, menurut majalah ini, ada masalah integritas dalam pengelolaan masa lalu. Ada masalah tata kelola dalam pengelolaan perbankan syariah. Pembiayaan bermasalah syariah lebih banyak menyisakan persoalan.

Beberapa bankir yang dihubungi majalah ini menyatakan banyak pembiayaan bermasalah yang menyisakan catatan hitam. Plus pendekatan pemberian pembiayaan lebih banyak bersifat "kedekatan" ketimbang sisi bisnis. Bank-bank syariah yang dikelola dengan tata kelola yang baik, hasilnya seperti yang sampai saat ini punya kinerja sangat baik. 
Perbankan syariah pernah menjadi primadona, bahkan disebut-sebut tahan krisis ketika terjadi krisis pada 1998 lalu. Bank syariah tidak mengalami masalah karena sistem bagi hasil. Namun, jika dilihat lebih dalam, sejatinya bukan semata bagi hasil. Waktu krisis lalu, portofolio pembiayaan bank syariah lebih dominan ke usaha kecil dan tidak ada unsur dolar. Bank-bank yang bermasalah adalah bank dengan pembiayaan dolar Amerika Serikat (AS) dan kredit korporasi.

Sementara, bank yang pembiayaan rupiah dan usaha kecil terus bertahan. Jadi, bukan semata-mata karena konsep bagi hasil dan tidak adanya unsur spekulasi. Namun, mengapa ketika bank-bank konvensional berkinerja sangat bagus di tengah tekanan NPL, bank syariah masih harus bergelut dengan lumpur pembiayaan bermasalah dan mencari tambahan suntikan modal.

Kegagalan lain bank syariah yang paling mendasar adalah menyangkut tata kelola dan mengelola risiko. Banyak bank syariah jatuh pada lubang yang sama, yaitu menyangkut tata kelola dan tergoda hendak membiayai apa yang dibiayai oleh bank konvensional. Padahal, kapasitas dan kemampuan SDM-nya tak memadai, maka lahirlah pembiayaan bermasalah.

Financial Sustainability Ratio adalah rasio untuk mengukur keberlanjutan suatu bank dari segi kinerja bank. Disamping itu juga sebagai target penambahan modal sendiri. Financial Sustainability Ratio (FSR) dapat digunakan untuk merencanakan tindakan yang harus dilakukan pada saat itu juga pada masa yang akan datang. (Amalia Rizky 2004). Financial Sustainability Ratio (FSR) adalah alat ukur untuk menilai efisiensi suatu lembaga (Soeksmono 1995:103 dalam Amalia Rizky 2004) rasio ini digunakan untuk mengetahui tingkat pertumbuhan tiap periodenya sehingga dapat diketahui kinerja dari keuangan bank tersebut untuk melaksanakan operasinya atau tidak.

Financial Sustainability adalah kemampuan suatu organisasi untuk membandingkan semua biaya (biaya keuangan, misalnya beban bunga atas pinjaman, dan biaya operasi, misalnya gaji pegawai, perlengkapan, persediaan) dengan uang atau pendapatan yang diterima dari kegiatan yang dilakukan (misalnya pendapatan bunga dan pendapatan dari deposito bank). Financial Sustainability terdiri dari dua komponen, yaitu expenses (beban), dan income (pendapatan). Financial sustainability dikatakan baik jika nilainya lebih besar dari 100\%, artinya bahwa total pendapatan harus lebih besar dari total biaya yang dikeluarkan.

Faktor-faktor yang mempengaruhi Sustainability Ratio salah satunya adalah Capital Adequacy Ratio (CAR). CAR merupakan kreteria dari aspek kecukupan modal (Capital), kecukupan modal merupakan hal penting dalam bisnis perbankan, bank yang memiliki tingkat kecukupan modal baik menunjukkan indikator sebagai bank sehat (Muhamad, 2015: 140). CAR menunjukkan kemampuan bank dalam menyediakan dana untuk keperluan pengembangan usaha serta menampung kemungkinan risiko kerugian yang diakibatkan dalam operasional bank. Semakin besar rasio tersebut akan semakin baik posisi modal. Berdasarkan ketentuan Bank for International Settlements, bank yang sehat harus memiliki CAR paling sedikit sebesar 8\% (Muhamad, 2015: 249 dan Muhamad, 2004: 103)

Dalam penelitian yang dilakukan oleh Iqbal, dan Anita (Juni, 2016) Tentang Analisis faktor-faktor yang memengaruhi Financial Sustainability Ratio (FSR) Pada Bank Umum Syariah di Indonesia Periode 2010-2014, tidak mempunyai pengaruh yang signifikan, hal ini bertentangan dengan penelitian yang dilakukan oleh Januar, dkk (2017), bahwa CAR berpengaruh signifikan terhadap Financial Sustainability Ratio (FSR).

Salah satu faktor yang memengaruhi FSR yaitu Non Performing Financing (NPF). NPF merupakan rasio kinerja keuangan dari aspek kualitas aktiva (Assets Quality) dari segi aktiva bermasalah, rasio ini digunakan untuk mengukur resiko terhadap kredit atau pembiayaan (Kasmir, 2012: 228). Yang dimaksud NPF atau pembiayaan bermasalah 
ialah pembiayaan yang telah tertunggak, melampaui masa akad perjanjian pengembalian sesuai dengan jenis pembiayaan. Jika persentase rasio ini besar berarti kemungkinan kegagalan pengembalian pembiayaan besar, artinya makin kecilpembiayaan bermasalah terhadap total pembiayaan yang diberikan berarti semakin baik kualitas kekayaan produktif bank dalam menghasilkan pendapatan (Widodo, et.al., 1999: 144). Dijelaskan bahwa Non Perfoming Financing (NPF) Berpengaruh signifikan terhadap Financial Sustainability Ratio (FSR), pada penelitian yang ditulis Iqbal, dan Anita (Juni, 2016).

Faktor lainnya yang menjadi pengaruh untuk Financial Sustainability Ratio (FSR) antara lain yaitu Laba Bersih, Laba Bersih perusahaan sangatlah berpengaruh demi kemajuan sebuah perusahaan yang dijalani untuk kedepannya, karena dari hal itu terlihat bagaimana dan apa yang harus dilakukan perusahaan kedepannya, demi meningkatkan kemajuan perusahaan yang dijalani tersebut, dan menentukan program yang akan dijalankan untuk kedepannya.

\section{Tujuan Penelitian}

1. Untuk mengetahui pengaruh Capital Adequacy Ratio (CAR) berpengaruh terhadap Financial Sustainability Ratio (FSR) pada perusahan perbankan Syariah yang berada di Indonesia tahun 2014-2018.

2. Untuk mengetahui pengaruh Non Performing Financing (NPF) berpengaruh terhadap Financial Sustainability Ratio (FSR) pada perusahan perbankan Syariah yang berada di Indonesia tahun 2014-2018.

3. Untuk mengetahui pengaruh Laba Bersihberpengaruh terhadap Financial Sustainability Ratio (FSR) pada perusahan perbankan Syariah yang berada di Indonesia tahun 2014-2018.

\section{LANDASAN TEORI}

\section{Prinsip Dasar Perbankan Syariah}

Menurut Undang- Undang No 21 tahun 2008 tentang Perbankan Syariah menyatakan bahwa Bank adalah badan usaha yang menghimpun dana masyarakat dalam bentuk simpanan dan menyalurkannya kepada masyarakat dalam bentuk kredit dan atau bentuk-bentuk lainnya dalam rangka meningkatkan taraf hidup rakyat banyak. Bank umum adalah bank yang melaksanakan kegiatan usaha secara konvensional dan atau berdasarkan prinsip syariah yang dalam kegiatannya memberikan jasa dalam lalu lintas pembayaran.

Di dalam undang-undang ini juga memuat tentang bank yang menjelaskan prinsip syariah dengan pengertian Prinsip Syariah adalah prinsip hukum Islam dalam kegiatan perbankan berdasarkan fatwa yang dikeluarkan oleh lembaga yang memiliki kewenangan dalam penetapan fatwa di bidang syariah.

Secara garis besar, hubungan ekonomi berdasarkan syariah islam tersebut ditentukan oleh akad hubungan akad yang terdiri dari lima konsep dasar akad. Bersumber dari kelima konsep dasar inilah dapat ditemukan produk-produk lembaga keuangan bank syariah dan lembaga keuangan bukan bank syariah untuk dioperasionalkan. Kelima konsep tersebut adalah: (1) sistem simpanan, (2) bagi hasil, (3) margin keuntungan, (4) sewa, (5) fee/jasa. (Muhammad, 85:2005)

Bank syariah mempunyai fungsi yang berbeda dengan bank konvensional dimana fungsi bank syariah merupakan karakteristik bank syariah. Dengan mengetahui fungsi bank syariah secara jelas akan membawa dampak dalam pelaksanaan kegiatan usaha bank syariah. berikut :

Menurut Muhammad (15:2005), fungsi bank syariah antara lain adalah sebagai 
- Memurnikan operasional perbankan syariah sehingga dapat lebih meningkatkan kepercayaan masyarakat.

- Meningkatkan kesadaran syariah umat Islam sehingga dapat memperluas segmen dan pangsa pasar perbankan syariah.

- Menjalin kerjasama dengan para ulama, sebab bagaimanapun juga peran ulama di Indonesia sangat dominan bagi kehidupan umat Islam.

\section{Commercial Loan Theory}

Commercial Loan Theory atau real bills doctrine atau productive theory of credit mulai dikenal sekitar abad 18. Kajian teori ini dilakukan oleh Adam Smith dalam bukunya yang terkenal The Wealth of Nation yang diterbitkan tahun 1776. teori ini beranggapan bahwa bank hanya boleh memberikan pinjaman dengan surat dagang jangka pendek yang dapat dicairkan dengan sendirinya (self liquiditing). Self Liquiditing berarti pemberian pinjaman mengandung makna untuk pembayaran kembali. Teori ini menyatakan secara spesifik bahwa bank- bank hanya akan memberikan kredit jangka pendek yang sangat mudah dicairkan atau likuid ("Short Term, Self Liquiditing") melalui pembayaran kembali (angsuran) atas kredit tersebut sebagai sumber likuiditas.

Esensi commercial loan theory dalam landasan penelitian ini adalah bank memberikan pembiayaan kepada masyarakat dengan perjanjian bagi hasil yang telah disepakati. Hal ini sesuai dengan fungsi dari perbankan syariah sebagai lembaga intermediasi, yaitu mengerahkan dana dari masyarakat dan menyalurkan kembali dana tersebut kepada masyarakat yang membutuhkannya dalam bentuk fasilitas pembiayaan atau financing yang memang adalah salah satu kegiatan utama dari bank tersebut untuk mendapatkan laba.

\section{Pembiayaan Bermasalah (Non Performing Financing)}

Dalam menunjukkan kemampuan manajemen bank dalam mengelola kredit bermasalah yang diberikan bank, bank konvensional biasanya menggunakan NPL (Non Performing Loan). NPL diukur dari rasio perbandingan antara kredit yang bermasalah dengan total kredit yang diberikan. NPF bertujuan untuk mengukur tingkat permasalahan pembiayaan yang dihadapi oleh bank. Semakin tinggi rasio ini, menunjukkan kualitas pembiayaan bank syariah semakin buruk. Pada bank syariah istilah NPL diganti dengan NPF karena dalam syariah menggunakan prinsip pembiayaan.

Pembiayaan merupakan aktivitas utama bank yang menghasilkan pendapatan bagi bank syariah. Investasi sejumlah dana kepada pihak lain dalam bentuk pembiyaan memiliki resiko gagal bayar dari nasabah pembiyaan. (Sasmita, 2014)

Pembiayaan merupakan aktivitas bank syariah dalam menyalurkan dana kepada pihak lain selain bank berdasarkan prinsip syariah. Penyaluran dana dalam bentuk pembiayaan didasarkan pada kepercayaan yang diberikan oleh pemilik dana kepada pengguna dana. Pemilik dana percaya kepada penerima dana, bahwa dana dalam bentuk pembiayaan yang diberikan pasti akan terbayar. Penerima pembiayaan mendapatkan kepercayaan dari pemberi pembiayaan, sehingga penerima pembiayaan berkewajiban untuk mengembalikan pembiayaan yang telah diterimanya sesuai dengan jangka waktu yang telah di perjanjikan dalam akad pembiayaan (Ismail, 2011).

Non Performing Financing merupakan tingkat risiko yang dihadapi bank. Non Performing Financing adalah jumlah kredit yang bermasalah dan kemungkinan tidak dapat ditagih. Adapun Non Performing Financing (NPF) dapat dihitung dengan rumus :

$$
\mathrm{NPF}=\frac{\text { Jumlah Pembiayaan Bermasalah }}{\text { Total Pembiayaan }} \times 100 \%
$$

Sumber : Iqbal \& Anita (2016) 


\section{Tingkat Kecukupan Modal (Capital Adequacy Ratio)}

Capital adequacy ratio (CAR) merepresentasikan penilaian terhadap aspek permodalan bank. Rasio CAR adalah kecukupan modal yang menunjukan kemampuan bank dalam mempertahankan modal yang mencukupi dan kemampuan manajemen bank dalam mengidentifikasi, mengukur, mengawasi dan mengontrol risiko-risiko yang dapat berpengaruh terhadap besarnya modal bank (Wibowo, 2008).

Berdasarkan pengertian para ahli mengenai pengertian CAR di atas, maka dapat disimpulkan bahwa CAR adalah untukmengukur kecukupan modal yang dimiliki bank untuk menunjang aktiva yang mengandung atau menghasilkan resiko, misal pembiayaan yang diberikan. Perhitungan kebutuhan modal didasarkan pada aktiva tertimbang menurut risiko (ATMR). Aktiva bank syariah dibagi atas :

a. Aktiva yang didanai oleh modal sendiri dan atau kewajiban atau hutang (wadie ${ }^{\text {ah }}$ atau qard dan sejenisnya).

b. Aktiva yang didanai oleh rekening bagi hasil yaitu Mudharabah, baik Mudharabah mutlaqah yang tercatat pada neraca maupun Mudharabah muqayyadah yang dicatat pada rekening administratif.

Berdasarkan pembagia jenis aktiva tersebut diatas, maka pada prinsipnya bobot bank syariah terdiri atas :

a. Aktiva yang dibiayai oleh modal bank sendiri dan atau dana pinjaman (wadi'ah,qard dan sejenisnya) adalah $100 \%$.

b. Aktiva yang dibiayai oleh pemegang rekening bagi hasil adalah $50 \%$.

Berdasarkan Deregulasi BI tertanggal 29 Febuari 1993, bank yang dinyatakan termasuk bank sehat (berkinerja baik) apabila memiliki CAR paling sedikit sebesar $8 \%$, sesuai dengan ketentuan yang ditetapkan oleh Bank for International Settlements (Wibowo: 2008). Semakin tinggi CAR maka semakin tinggi pula bank melakukan penyaluran pembiayaannya. Begitu juga sebaliknya, semakin rendah CAR maka semakin rendah pula pembiayaan yang disalurkan oleh bank.

Menurut Peraturan Bank Indonesia Nomoe 3/21/PBI/2001, bank wajib menyediakan modal minimum sebesar $8 \%$ dari akva tertimbang menurut risiko yang dinyatakan dalam rasio Capital Adequacy Ratio (CAR). Rasio ini bertujuan untuk memastikan bahwa jika dakam aktiva bank mengalami kerugian, maka ketersediaan modal yang dimiliki oleh bank mampu mengcover kerugian tersebut.

$$
\text { Capital Adequacy Ratio }=\frac{\text { Modal }}{\text { ATMR }} \times 100 \%
$$

\section{Laba Bersih}

Menurut Hansen dan Mowen (2009:803) dalam bukunya yang berjudul Manajemen Biaya, menyatakan bahwa laba bersih adalah pendapatan bersih yang telah dikurangi pajak. Laba bersih menunjukkan penilaian yang relavan bagi seorang investor untuk menilai efektifitas manajemen dan kebijakan pembayaran dividen yang akan diterima sebagai keuntungan dari penanaman saham hal ini sesuai dengan teori keuangan yang menyatakan bahwa laba bersih digunakan sebagai ukuran jumlah maksimal dana yang akan dibagikan sebagai dividen. Menurut Adiwiratama (2012) dalam penelitiannya yang berjudul Pengaruh Informasi Laba, Arus Kas, dan Size Perusahaan Terhadap Return Saham (Studi Empiris Pada Perusahaan Manufaktur yang Terdaftar di BEI), laba bersih adalah selisih dari pendapatan di atas biaya-biayanya dalam jangka waktu (periode) tertentu.

Sedangkan menurut Liawani (2013) dalam penelitiannya yang berjudul Analisis Hubungan Antara Laba Akuntansi dan Laba Tunai Dengan Dividen Kas Pada Perusahaan 
Manufaktur Yang terdaftar Di Bursa Efek Indonesia (BEI) menyatakan bahwa laba bersih merupakan laba akuntansi, yaitu perbedaan antara realisasi penghasilan yang berasal dari transaksi perubahan pada periode tertentu dikurangi dengan biaya yang dikeluarkan untuk mendapatkan penghasilan itu. Laba bersih di ukur dengan menggunakan selisih antara pendapatan yang direalisir dari transaksi pada periode tertentu dikurangi dengan biaya yang dikeluarkan oleh periode yang sama. Berdasarkan dari tigaperbandingan sumber diatas, dapat disimpulkan bahwa laba bersih suatu perusahaan apabila dilihat dari laporan laba rugi adalah merupakan jumlah selisih antara laba kotor suatu perusahaan (penjualan bersih dikurangi harga pokok penjualan) dengan beban-beban operasional dan beban diluar operasional perusahaan kemudian ditambahkan pendapatan diluar operasional dan dikurangi oleh pajak penghasilan.

\section{Finacial Sustainability Ratio (FSR)}

Financial Sustainability Ratio adalah rasio untuk mengukur keberlanjutan suatu bank dari segi kinerja bank. Disamping itu juga sebagai target penambahan modal sendiri. Financial Sustainability Ratio (FSR) dapat digunakan untuk merencanakan tindakan yang harus dilakukan pada saat itu juga pada masa yang akan datang. (Amalia Rizky 2004). Financial Sustainability Ratio (FSR) adalah alat ukur untuk menilai efisiensi suatu lembaga (Soeksmono 1995:103 dalam Amalia Rizky 2004) rasio ini digunakan untuk mengetahui tingkat pertumbuhan tiap periodenya sehingga dapat diketahui kinerja dari keuangan bank tersebut untuk melaksanakan operasinya atau tidak. Financial Sustainability (www.wbln0018.worldbank) adalah kemampuan suatu organisasi untuk membandingkan semua biaya (biaya keuangan, misalnya beban bunga atas pinjaman, dan biaya operasi, misalnya gaji pegawai, perlengkapan, persediaan) dengan uang atau pendapatan yang diterima dari kegiatan yang dilakukan (misalnya pendapatan bunga dan pendapatan dari deposito bank). Financial Sustainability terdiri dari dua komponen, yaitu expenses (beban), dan income (pendapatan). Financial sustainability dikatakan baik jika nilainya lebih besar dari $100 \%$, artinya bahwa total pendapatan harus lebih besar dari total biaya yang dikeluarkan. Besarnya FSR diambil dari total pendapatan fi nancial dibandingkan dengan totalbeban financial pada laporan laba rugi. Rasio ini dihitung denganmenggunakan :

$$
\text { FSR }=\frac{\text { Total Pendapatan Financial }}{\text { Total Beban Financial }} \text { X 100\% }
$$

Sumber : Iqbal \& Anita (2016)

\section{A. Kerangka Konseptual}

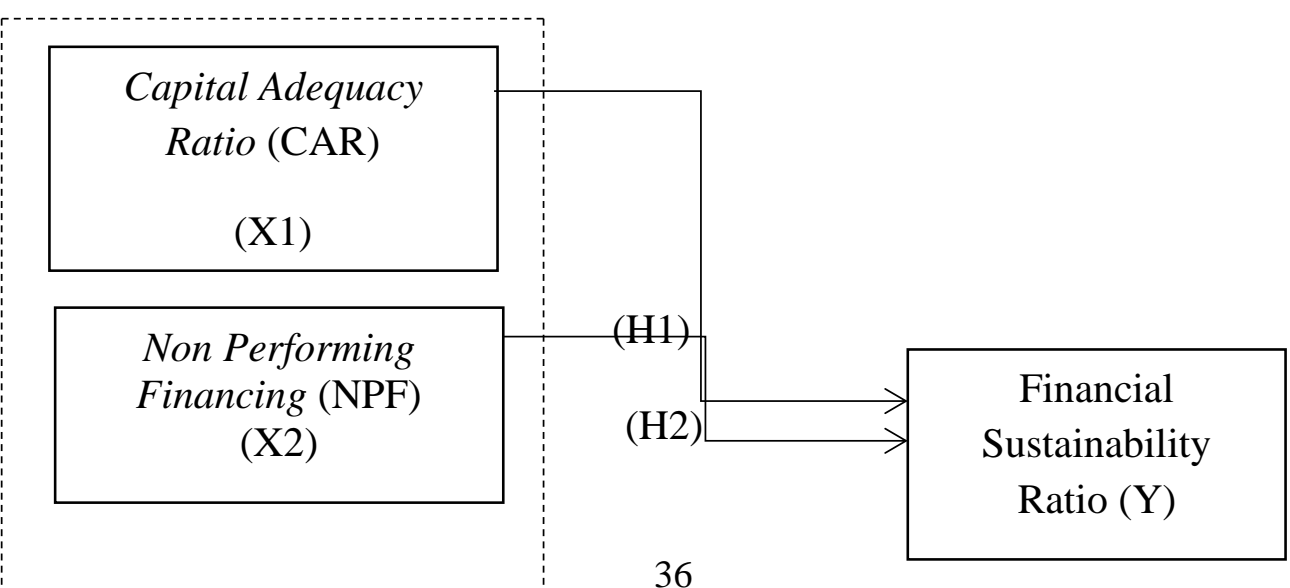




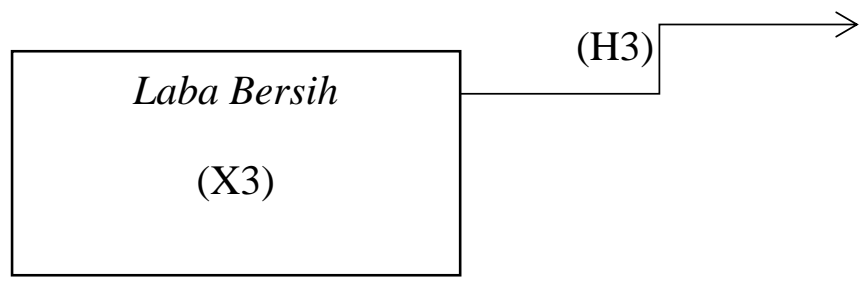

Gambar 2.1

Kerangka Konseptual

\section{Perumusan Hipotesis}

\section{a. Pengaruh Capital Adequacy Ratio (CAR) terhadap Financial} Sustainability Ratio (FSR)

Rasio kecukupan modal (CAR) atau modal untuk rasio aset berbobot risiko adalah suatu cara untuk mengukur modal bank, yang ditunjukkan sebagai pembukaan kredit berbobot risiko bank. Rasio ini digunakan untuk melindungi depositor dan menaikkan stabilitas dan efisiensi sistem keuangan di seluruh dunia. Artinya dengan cukupnya cover kecukupan modal yang telah di tentukan dapat mempengaruhi untuk berjalannya kinerja perbankan (FSR) untuk kedepannya.

Menurut Sri Wahyuni dan Iwan (2014) Capital Adequacy Ratio mempunyai pengaruh yang signifikan terhadap Financial Sustainability Ratio. Jadi dapat dikatakan bahwa Tingkat Kecukupan Modal (CAR) memiliki pengaruh terhadap Kelanjutan Bank Tersebut (FSR). Berdasarkan hal tersebut maka dapat disimpulkan bahwa :

H1 : Capital Adequacy Ratio (CAR) berpengaruh signifikan terhadap Financial Sustainability Ratio (FSR)

b. Pengaruh Non Performing Financing (NPF) terhadap Financial Sustainability Ratio (FSR)

Non Performing Financing / Pembiayaan Bermasalah (NPF) adalah kredit bermasalah yang terdiri dari kredit yang berklasifikasi kurang lancar, diragukan dan macet. Dapat disimpulkan pula macetnya pembiayaan, akan membuat cashflow yang sebelumnya telah di rencanakan menjadi tidak berjalan sesuai rencana, dan harus membuat ulang cashflow sesuai dengan dana yang berjalan diluar dari pembiayaan yang macet tersebut, sehingga sangat berpengaruh dalam kinerja perbankan yang tidak seperti di rencanakan sebelumnya.

Iqbal dan Anita (2016) berpendapat bahwa Non Performing Financing (NPF) berpengaruh Positif terhadap Financial Sustainability Ratio (FSR). Dan dapat disimpulkan bahwa Pembiayaan Bermasalah (NPF) dapat mempengaruhi Kelanjutan Bank Tersebut (FSR). Berdasarkan hal tersebut maka dapat disimpulkan bahwa :

H2 : Non Performing Financing (NPF) berpengaruh signifikan terhadap Financial Sustainability Ratio (FSR)

c. Pengaruh Laba Bersih terhadap Financial Sustainability Ratio (FSR)

Laba bersih adalah kelebihan seluruh pendapatan atas seluruh biaya untuk suatu periode tertentu setelah dikuarangi pajak penghasilan yang disajikan dalam bentuk laporan laba rugi.

Laba bersih dapat berarti berbeda-beda, sehingga selalu membutuhkan klarifikasi. Laba bersih yang ketat berarti setelah semua pemotongan (sebagai lawan hanya pemotongan tertentu yang digunakan terhadap laba kotor atau marjin). Laba bersih biasanya mengacu pada laba setelah dikurangi semua 
biaya operasi, terutama setelah dikurangi biaya tetap atau biaya overhead tetap. Hal ini berbeda dengan laba kotor yang biasanya mengacu pada selisih antara penjualan dan biaya langsung produk atau jasa yang dijual (juga disebut sebagai marjin kotor atau marjin laba kotor) dan tentunya sebelum dikurangi biaya operasi atau biaya overhead. Laba bersih biasanya mengacu pada angka laba sebelum dikurangi pajak perusahaan, dalam hal ini istilah yang sering digunakan adalah laba bersih sebelum pajak (earning before tax atau EBT). Laba Bersih terdapat pada laporan bulanan, dan sangat berpengaruh untuk perencanaan kinerja Perbankan kedepannya, sehingga perencanaan bisa disesuaikan dengan jumlah pendapatan yang terdapat pada Laporan Laba Rugi, sehingga bisa untuk memprediksi penjualan, biaya, dan mengontrol cost yang ada pada Laporan Laba Rugi Perbankan.

Menurut Hansen dan Mowen (2009:803) Laba bersih menunjukkan penilaian yang relavan bagi seorang investor untuk menilai efektifitas manajemen dan kebijakan pembayaran dividen yang akan diterima sebagai keuntungan dari penanaman saham hal ini sesuai dengan teori keuangan yang menyatakan bahwa laba bersih digunakan sebagai ukuran jumlah maksimal dana yang akan dibagikan sebagai dividen. Maka dapat disimpulkan bahwa Laba Bersih dapat mempengaruhi Kelanjutan Bank Tersebut (FSR).

H3 : Laba Bersih berpengaruh signifikan terhadap Financial Sustainability Ratio (FSR)

\section{METODE PENELITIAN}

Jenis data yang digunakan dalam penelitian ini adalah data sekunder yang diambil dari laporan tahunan 2014 sampai dengan 2018 yang sudah dipublikasi di Bursa Efek Indonesia (www.idx.co.id). Jumlah perusahaan yang dijadikan sample perusahaan adalah sebanyak 9 yang berkategori Perbankan Syariah.

Tabel 4.1

Kriteria Pemilihan Sampel

\begin{tabular}{|c|l|c|}
\hline No. & \multicolumn{1}{|c|}{ Kriteria } & Jumlah \\
\hline 1. & $\begin{array}{l}\text { Perusahaan Bank Syariah yang terdaftar di Indonesia selama } \\
\text { periode 2014-2018 }\end{array}$ & $\mathbf{1 1}$ \\
\hline $2 . \quad \begin{array}{l}\text { Perusahaan yang tidak memiliki laporan keuangan lengkap } \\
\text { periode tahun 2014-2018 }\end{array}$ & $\mathbf{( 2 )}$ \\
\hline \multicolumn{2}{|l|}{ Jumlah Perusahaan yang menjadi sampel penelitian } & $\mathbf{9}$ \\
\hline Jumlah Periode Penelitian (tahun) & $\mathbf{5 5}$ \\
\hline \multicolumn{2}{|l|}{ Jumlah Data Observasi Penelitian } \\
\hline
\end{tabular}

Sumber: Data yang diolah, 2018

Berdasarkan kriteria pengambilan sampel di atas perusahan Bank Syariah yang telah memenuhi kriteria sebagai sampel penelitian sebanyak 9 perusahan selama lima tahun penelitian, sehingga jumlah data yang akan digunakan pada penelitian ini adalah sebanyak 45 data observasi.

\section{Metode Analisis Data}


Teknik analisis yang digunakan dalam penelitian ini adalah teknik kuantitatif. Penulis membandingkan variabel independen dan variabel dependen dengan menggunakan perhitungan. Teknik analisis data yang dilakukan dalam penelitian ini yaitu dengan menggunakan analisis statistik yang menggunakan perangkat lunak yaitu EVIEWS 9 dan bertujuan untuk menguji kebenaran hipotesis.

Adapun metode analisis data yang digunakan tidak seperti regresi biasanya, regresi data panel melalui tahapan penentuan model estimasi model regresi dengan menggunakan data panel dapat dilakukan melalui tiga pendekatan, antara lain:

1. Common Effect Model, Analisis model common effect merupakan teknik yang paling sederhana mengansumsikan bahwa data gabungan yang ada menunjukan data yang sesungguhnya. Dalam pendekatan estimasi ini, tidak diperlihatkan dimensi individu maupun waktu. Diasumsikan bahwa perilaku data antar perusahaan sama dalam berbagai kurun waktu. (Winarno, 2015: 9.14)

2. Fixed Effect Model, Menurut winarno (2015: 9.10) diperlukan suatu model yang dapat menunjukan perbedaan konstanta antar objek meskipun dengan koefisien yang sama model ini dikenal dengan nama model efek tetap atau fixed effect

3. Random Effect Model(Winarno, 2015). Selain dengan metode efek tetap, kita juga dapat menganalisis data panel dengan menggunakan efek random. Efek random digunakan untuk mengatasi kelemahan metode efek tetap yang menggunakan variabel semu, metode efek random menggunakan residual, yang diduga memiliki hubungan antarwaktu dan antar objek (Winarno, 2015: 9.17)

Setelah melakukan uji-uji dalam mencari pendekatan estimasi yang terbaik dalam regresi data panel maka selanjutnya akan dilakukan analisis sebagai berikut:

1. Uji asumsi klasik menggunakan; a) Uji multikolinearitas, bertujuan untuk menguji apakah dalam model regresi panel ditemukan adanya korelasi antar variabel independen. Untuk menguji masalah multikolinearitas dapat melihat matriks korelasi dari variabel bebas, jika terjadi koefisien korelasi lebih dari 0,80 maka terdapat multikolinearitas (Gujarati, 2007); b) uji heteroskedastisitas, dilakukan untuk mengetahui ada atau tidaknya ketidaksamaan varian dari residual model regresi data panel. Ketentuan yang digunakan, jika nilai probabilitasnya tidak signifikan secara statistik pada derajat 5\% maka hipotesis nol diterima, yang berati tidak ada heteroskedastisitas dalam model (Gujarati, 2007).

2. Analisis regresi data panel, adalah analisis regresi dengan struktur data yang merupakan data panel. Umumnya pendugaan parameter dalam analisis regresi dengan data cross section dilakukan menggunakan pendugaan metode kuadrat terkecil atau disebut Ordinary Least Square (OLS). Data panel (pooled data) diperoleh dengan cara menggabungkan data time series dengan cross section.

$$
Y_{i t}=\alpha+\beta_{1} X_{1 i t}+\beta_{2} X_{2 i t}+\beta_{3} X_{3 i t}+\ldots+\beta_{n} X_{n i t}+e_{i t}
$$

3. Uji $\mathrm{R}^{2}$ koefisien determinasi dilakukan untuk melihat seberapa jauh kemampuan model dalam menerangkan variasi variabel bebas mempengaruhi variabel terikat (Ghozali, 2005). Nilai $\mathrm{R}^{2}$ berada antara 0 dan 1 . Semakin mendekati 1 atau $100 \%$ maka semakin besar pengaruh variabel independen terhadap variabel dependen.

4. Uji statistik, untuk menguji apakah pengaruh signifikan atau tidak maka perlu dihitung nilai t dengan interval keyakinan (level of signification) 95\%, $\alpha=5 \%$ dan derajat kebebasan (degree of freedom) atau dengan melihat nilai signifikansi dibandingkan dengan alpha $5 \%$.

\section{HASIL PENELITIAN DAN PEMBAHASAN}

Berdasarkan pengujian perpasangan terhadap ketiga model regresi data panel tersebut, seperti yang ditunjukkan dalam tabel 2, dapat disimpulkan bahwa Random Effect Model (REM) dalam regresi data panel dapat digunakan lebih lanjut untuk 
menganalisis secara simultan dan parsial apakah CAR, NPF dan nilai perusahaan berpengaruh terhadap FSR pada perusahaan sektor Bank Syariah.

Kesimpulan Model

\begin{tabular}{|c|c|c|c|}
\hline No & Metode & Pengujian & Hasil \\
\hline 1 & Uji Chow & CEM vs FEM & FEM \\
\hline 2 & Uji Hausman & REM vs FEM & REM \\
\hline 3 & Uji Lagrange Multiplier & CEM vs REM & REM \\
\hline
\end{tabular}

Menurut A.Basuki \& N. Prawoto (2017) keuntungan menggunakan REM ini adalah yakni menghilangkan heteroskedastisitas (uji asumsi klasik). Model ini juga disebut dengan Error Component Model atau teknik Generalized Least Square.

\section{Uji Hipotesis}

Uji F

Hasil Uji F menjelaskan apakah semua variabel bebas yang dimasukan ke dalam model secara simultan atau bersama-sama mempunyai pengaruh terhadap variabel terikat, atau dengan kata lain model fit atau tidak.

Dependent Variable: FSR

Method: Panel EGLS (Cross-section random effects)

Periods included: 5

Cross-sections included: 9

Total panel (balanced) observations: 45

Swamy and Arora estimator of component variances

\begin{tabular}{crlrl}
\hline \hline Variable & Coefficient & Std. Error & t-Statistic & Prob. \\
\hline \hline C & 2.622625 & 0.480590 & 5.457093 & 0.0000 \\
CAR & -1.262502 & 0.611467 & -2.064711 & 0.0453 \\
NPF & -15.22963 & 9.102822 & -1.673067 & 0.1019 \\
NP & -0.786848 & 0.178101 & -4.417980 & 0.0001 \\
\hline \hline & Weighted Statistics & \\
\hline \hline R-squared & 0.310132 & Mean dependent var & 0.463498 \\
Adjusted R-squared & 0.259653 & S.D. dependent var & 0.604792 \\
S.E. of regression & 0.520384 & Sum squared resid & 11.10277 \\
F-statistic & 6.143874 & Durbin-Watson stat & 1.620759 \\
Prob(F-statistic) & 0.001505 & & & \\
\hline \hline
\end{tabular}

Sumber :Output Eviews V9

Persamaan regresi didapatkan sebagai berikut:

FSR $=2.622625-1.262502 \mathrm{CAR}-15.22963 \mathrm{NPF}-0.786848 \mathrm{NP}+\varepsilon_{i t}$

Dari persamaan di atas dijelaskan bahwa:

a. NilaiFinancial Sustainability Ratio (FSR) dalam penelitian ini adalah sebesar 2.622, Jika variabel independen dalam penelitian ini bernilai konstan (nol). 
b. Nilai koefisien capital adequacy ratio (CAR) sebesar 1.262502, menunjukkan bahwa setiap kenaikan 1.26 pada CAR diikuti dengan penurunan FSR dengan asumsi koefisien lainnya bernilai konstan.

c. Nilai koefisien non performing financing (NPF) sebesar 15.22963, menunjukkan bahwa setiap kenaikan 15.88 pada NPF diikuti dengan penurunan FSR.

d. Nilai koefisien net profit (NP) sebesar 0.786848, menunjukkan bahwa setiap kenaikan 0.78 pada Laba Bersih (NP) diikuti dengan penurunan FSR.

Pada tabel diatas menunjukkan bahwa nilai F-statistic sebesar 6.143874, sementara F Tabel dengan tingkat $\alpha=5 \%$, df1 $(\mathrm{k}-1)=(4-1)=3$ dan df $2(\mathrm{n}-\mathrm{k})=(9$ perusahaan $\mathrm{x} 5)$ $-4)=41$ didapat nilai F Tabel sebesar 2.83. Dengan demikian F-statistic (3.818183) $>$ F Tabel (2.46) dan nilai Prob (F-statistic)0.001505< 0.05 maka dapat disimpulkan bahwa Ha diterima, maka dengan demikian dapat disimpulkan bahwa variabel-variabel independen dalam penelitian ini yang terdiri dari Capital Adequacy Ratio, Non Performing Financing, dan Net Profit secara bersama-sama memiliki pengaruh terhadap Financial Sustainability Ratio. Artinya uji model penelitian ini layak untuk dilanjutkan.

Pada tabel diatas pula menunjukkan nilai Adjusted R-squared sebesar 0,25, artinya bahwa variasi perubahan naik turunnya Financial Sustainability Ratio dapat dijelaskan dengan CAR, NPF, dan NP sebesar 25\% sedangkan sisanya $75 \%$ disebabkan oleh variabel atau hal lain diluar dari variabel yang diteliti.

Berdasarkan pengujian hipotesis t, dapat diketahui bahwa variabel CAR memiliki tstatistic < ttabel $(-2.064711>1.68288)$ dengan nilai signifikasi $0.0453<$ taraf signifikasi 0.05 maka dapat disimpulkan bahwa Ha diterima artinya dalam penelitian ini CAR berpengaruh negatif terhadap Financial Sustainability Ratio. Menurut Muhammad (2013), CAR merupakan kreteria dari aspek kecukupan modal (Capital), kecukupan modal merupakan hal penting dalam bisnis perbankan, bank yang memiliki tingkat kecukupan modal baik menunjukkan indikator sebagai bank sehat (Muhamad, 2015: 140). CAR menunjukkan kemampuan bank dalam menyediakan dana untuk keperluan pengembangan usaha serta menampung kemungkinan risiko kerugian yang diakibatkan dalam operasional bank. Semakin besar rasio tersebut akan semakin baik posisi modal. Berdasarkan ketentuan Bank for International Settlements, bank yang sehat harus memiliki CAR paling sedikit sebesar 8\% (Muhamad, 2015: 249 dan Muhamad, 2004: 103).

Berdasarkan pengujian diatas dapat diketahui bahwa variabel NPF memiliki tstatistic $<$ ttabe $(-1.540215<1.68288)$ dengan nilai signifikasi $0.1019>$ taraf signifikasi 0.05 maka dapat disimpulkan bahwa H0 diterima, artinya NPF tidak berpengaruh terhadap Financial Sustainability Ratio. Dalam penelitian ini NPF tidak berpengaruh terhadap FSR. Yang dimaksud NPF atau pembiayaan bermasalah ialah pembiayaan yang telah tertunggak,melampaui masa akad perjanjian pengembalian sesuai dengan jenispembiayaan. Jika prosentase rasio ini besar berarti kemungkinankegagalan pengembalian pembiayaan besar, artinya makin kecilpembiayaan bermasalah terhadap total pembiayaan yang diberikanberarti semakin baik kualitas kekayaan produktif bank dalammenghasilkan pendapatan (Widodo, et.al., 1999: 144) (Shanie dkk, 2014). Maka dari itu pembiayaan macet tidak bisa juga dijadikan acuan bahwa NPF berpengaruh terhadap FSR, karena bisa saja manajemen memberikan produk perbankan yang tadinya dinilai kurang bagus menjadi semenarik mungkin demi mencari para investor dan nasabah Bank.

Berdasarkan pengujian diatas dapat diketahui bahwa variabel DER memiliki $t_{\text {statistic }}$ $<\mathrm{t}_{\text {tabel }}(-4.417980<1.68288)$ dengan nilai signifikasi $0.0001<$ taraf signifikasi 0.05 maka dapat disimpulkan bahwa Ha diterima, artinya Net Profitberpengaruh Negatif terhadap Financial Sustainability Ratio. Dari sisi investor, Laba bersih merupakan fokus utama 
pihak eksternal dalam membuat keputusan investasi. Atas dasar itulah investor lebih memperhatikan angka laba perusahaan dengan alasan bahwa investor berasumsi perusahaan Oleh karena itu besarnya variable ini mempengaruhi respon investor secara langsung terhadap Kinerja perbankan kedepannya (FSR). Serta menurut Hansen dan Mowen (2009:803) Laba bersih menunjukkan penilaian yang relavan bagi seorang investor untuk menilai efektifitas manajemen dan kebijakan pembayaran dividen yang akan diterima sebagai keuntungan dari penanaman saham hal ini sesuai dengan teori keuangan yang menyatakan bahwa laba bersih digunakan sebagai ukuran jumlah maksimal dana yang akan dibagikan sebagai dividen. Maka dapat disimpulkan bahwa Laba Bersih dapat mempengaruhi Kelanjutan Bank Tersebut (FSR).

\section{DAFTAR PUSTAKA}

Agus Tri Basuki And Prawoto, Nano. 2017. Analisis Regresi Dalam Penelitian Ekonomi \& Bisnis : Dilengkapi Aplikasi SPSS \& EVIEWS. PT Rajagrafindo Persada, Depok.

Hansen Don R, Mowen M. M., 1999, Akuntansi Manajemen, Jilid 2, Edisi ...

Empat. Hansen Dan Mowen, 2009, Akuntansi Manajemen, Edisi 8, Jakarta, Penerbit.

Iqbal \& Anita, Juni 2016, ANALISIS FAKTOR-FAKTOR YANG MEMENGARUHI

FINANCIAL SUSTAINABILITY RATIO PADA BANK UMUM SYARIAH DI INDONESIA PERIODE 2010 - 2014

Kasmir. (2012), Analisis Laporan Keuangan. Jakarta : PT. Raja Grafindo Persada. Hery.

(2012), Rahasia Cermat Dan Mahir Menganalisis Laporan Keuangan.

Liawani, 2013. ANALISIS HUBUNGAN ANTARA LABA AKUNTANSI DAN LABA TUNAI DENGAN DIVIDEN KAS.

Muhamad, 2015:, ANALISIS FAKTOR-FAKTOR YANG MEMENGARUHI

FINANCIAL SUSTAINABILITY RATIO PADA BANK UMUM SYARIAH DI INDONESIA PERIODE 2010-2014

Rizky, Amalia K.P. 2004. Analisis Faktor-Faktor Yang Mempengaruhi Sustainability Ratio Perbankan Syariah Di Indonesia

Wahyuni, Sri \& Fakhruddin, Iwan. 2014, Analisis Faktor-Faktor Yang Mempengaruhi Sustainability Ratio Perbankan Syariah Di Indonesia

Www.Wbln0018.Worldbank 